\title{
A study on impact of residential property value based on designated heritage property with special reference to the city of Kandy-Sri Lanka
}

\author{
Uditha Jayampath ${ }^{1}$ \& Prathibhani Bandusena \\ Department of Town and Country Planning, University of Moratuwa, Sri Lanka
}

\begin{abstract}
Real properties are fixed assets with a bundle of rights. Thus, the freehold property owners could possess, use, abuse and even destroy his real property. However, the rate of re-development and high demand has directly affected the increase of a clear site value of the property than the present capital value of the property. Further, the property owner always considers the highest and the best use of the property. In this situation, there is a less possibility for redevelopment of the property as there is reason for legal restraints of the heritage-designated property. Harvey \& Jowsey (2004)) introduces methods of preserving a historic building, when a period of time the clear site value has been increasing than the present capital value of the property. In addition, after a period, 'value as a historic house' the heritage property value increases than the clear site value. However, heritage properties generally performs well and has a significant demand in the market. Few researchers had identified that there were less/no-observable impact on the property value of heritage-designated property. Therefore, this research focuses on the investigation of the impact of heritage designation on the residential property value in Kandy in Sri Lanka with reference to the methods introduced by Jack Harvey in 2004 on preserving a historic building through the given methods. This research was a case based study, which consists of a literal review, a detailed survey and analysis. The Kandy world heritage city was selected as the case study where 112 residential properties were designated as heritage property in 1987 in Kandy. These 112 heritage designated residential properties were selected as the sample and a detailed survey was carried out based on observations and interviews. Further, both quantitative and qualitative methods were applied for the analysis. The quantitative analysis was carried out by using a linear regression model. Both qualitative and quantitative analysis showed that the small-scale properties have less possibility to increase their present capital value of the property than the clear site value of the property. Further, when declaring heritage properties, it is essential to consider the scale of the property and the level of its contribution to the city image as a heritage property. Moreover, the government intervention is also essential to improve those heritage properties.
\end{abstract}

Keywords: Heritage designation, Residential property value, Real property market

\section{Introduction}

For the purpose of urban conservation, both residential and commercial properties have been designated as heritage properties. In Sri Lanka, there are many residential properties within world heritage cities declared under the preview of The United Nations Educational, Scientific and Cultural Organization (UNESCO) which have obtained heritage designation considering its values of archeological, cultural and architectural etc.

Heritage designation is an extra legal restrain which do not cover other properties in same real property market. Heritage designation of residential property and its' real property values are two varieties. This research investigates about the impacts on residential

\footnotetext{
${ }^{1}$ Corresponding Author

(iD) https://orcid.org/0000-0003-0564-908X

Email address: udithajayampath@gmail.com, prathibhanipb@gmail.com

DOI: http://doi.org/10.4038/bhumi.v5i2.31
} 
property once it has been designated as a heritage property.

\section{Heritage Designation Residential Property Value}

and

"Where land is already developed by having a building on it, fixed capital is embodied in the land. Such capital has no cost in short periods; as a result, redevelopment to a new use, which requires expenditure of further capital, usually occurs only after a considerable period of time" (Harvey \&Jowsey (2004)). This occurs when the operating costs of a building increase than the expected gross annual return of it. This is explained in figure no.1. According to that, the expected gross annual return in year ' $Z$ ' is reduces than the operating cost.

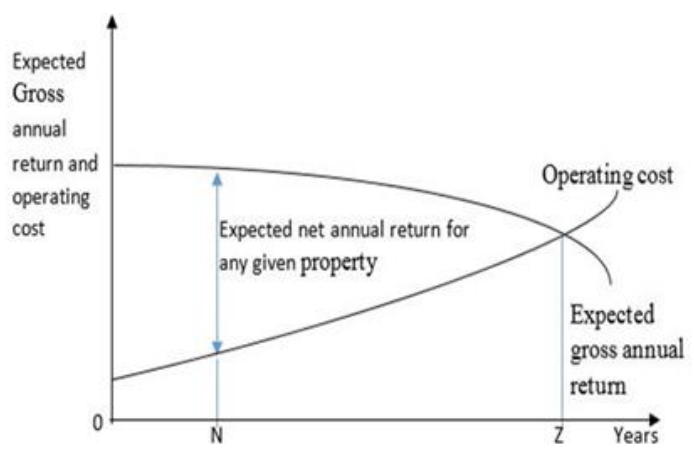

Figure 1: Gross annual return and operating cost over time

(Source: Urban Land Economics, Jack Harvey 2004)

"Conservation is not limited to mere preservation but seeks creative continuity by promoting vitality of use of the environment while ensuring that changes is sympathetic to the quality of life of both present and future generation (Harvey \& Jowsey (2004))". Further, Harvey \& Jowsey (2004) mentioned that a property to be considered as a real property should possess four aspects of rights. The first is the 'Free simple absolute', which means that the owner can possess, use, abuse and even destroy his real property. This right is limited to the Property owner who can only use his or her property subject to other people's property rights and the Property owner is subjected to the legal restraints imposed by planning acts, building regulation and similar legislation. When a property is designated as a heritage property, it is bound by extra-legal resistance, however other ancillary properties are not covered in the same real property market with these legal resistances. On the other hand when the expected gross annual income of year ' $Z$ ' (refer figure 1) reduces than the operating cost, the annual rate of return becomes negative. Moreover, under that situation, a heritage-designated property has less possibility for redevelopment and there is no possibility to clear the site.

Further, Harvey \& Jowsey (2004) explained that heritage designated property has external benefits like aesthetic appeal of a historical building. As a result, there is a 'shadow' price, which substitutes for all its weaknesses. This is illustrated in figure no.2.

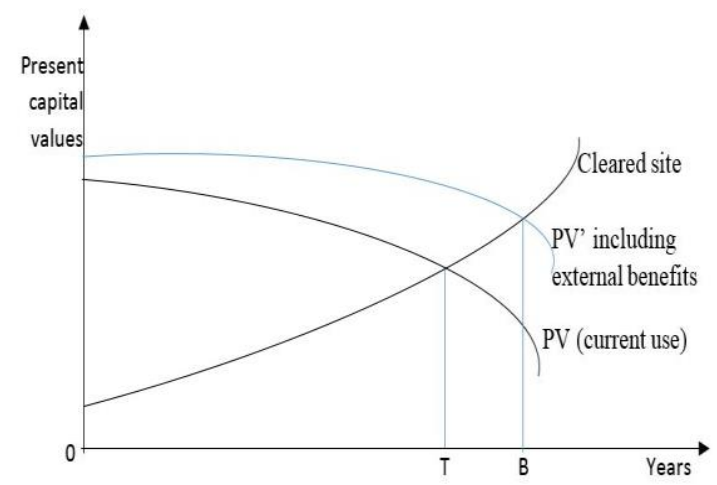

Figure 2: Adjustment to the present-value of a historic building for deferent use

(Source: Urban Land Economics, Jack Harvey, 2004)

If left to the market forces, year ' $\mathrm{T}$ ' is the demolition year of the historic building as cleared site value and the present value of the heritage-designated property is equal. As a result of external benefits (eg: reason to aesthetic appeal of historic building attracts tourists in to the area) there is an optional 
demand, which has been created postponing the demolition to year B.

Moreover, Harvey \& Jowsey (2004) have introduced a method of preserving a historical building. According to the figure 3,

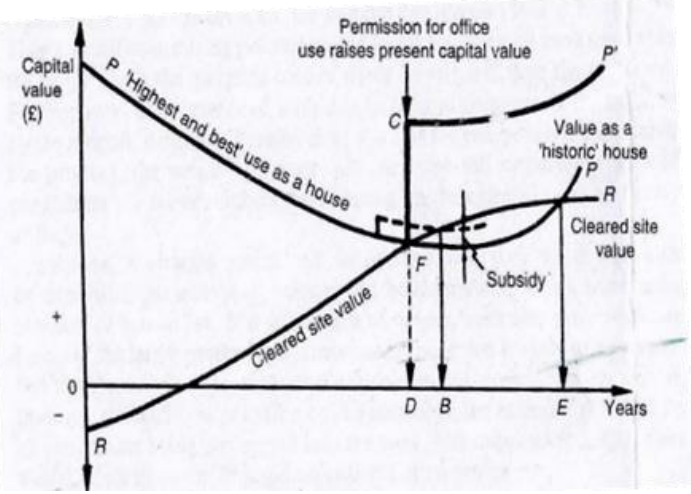

Figure 3: Method of preserving a historic building (Source: Urban Land Economics, Jack Harvey, 2004)

in year ' $\mathrm{D}$ ', the highest and the best use of the heritage property as a house reduces than the clear site value. However, in the year ' $E$ ', the value of heritage designated property increases than the clear site value. Heritage designated property has a perfect inelastic supply, however, there is no alternative supply for heritage designated property. As a result of that, at period ' $E$ ', heritage designated property value increases than the clear site value. Further, as per Harvey \& Jowsey (2004), the government has to become involved in the period between ' $\mathrm{D}$ ' $\&$ ' $E$ ' to designate free operation of the price system in order to preserve the historic building (e.g.: giving property tax concessions), otherwise in year ' $\mathrm{D}$ ' changing of the use of historical building will be the reason for the increase in the present capital value of the historical buildings.

Dubben \& Wiliams (2009) has explained the life cycles in buildings and their property development implications. According to that, the replacement or refurbishment of a building occurs when the value of the site exceeds the real value of existing building.
This increase in site value occurs owing to the nature of the pricing system that reflects hope or potential value in site prices. Planning regulations like conservation and preservation prevent the demolition of such buildings.

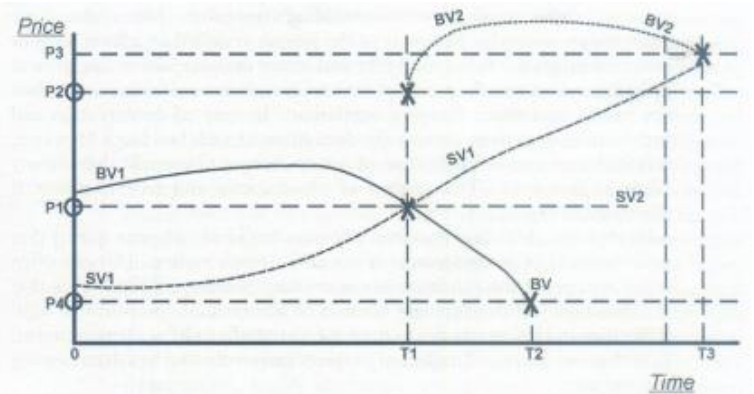

Figure 4: Development cycles of individual buildings

(Source: Partnerships in Urban Property Development, Nigel Dubben \& Brendan Williams, 2009)

Notes: SV = Site value, BV = building value

Above diagram indicates the relationship between site prices, building prices and real demand of the property. "At price 1 (P1) the initial relationship at inception of site value situated at one-third of building value has moved to parity (Dubben \& Wiliams (2009)". From the T1 the maintenance cost of the building increases and the site has become more valuable than the building. "Building value now moves to a new level BV2, with the life span of the building extended by a further period of 20 years plus to T3, at which point redevelopment occurs again (Dubben \& Wiliams;2009)". If the development or redevelopment has not occurred, the real value of the building will decrease until T2 and site would acquire a stable value (SV2).

Moreover many scholars have done researchers on how the heritage designation impact on residential property value. When measuring the impact of heritage designation on residential property value they have used different methods. Shipley, R. (2000) identifies that heritage designated properties generally perform well in the market with 
$74 \%$ doing average or better than average. According to the analysis he used the selling price of selected properties (heritage designated properties and other properties) including 3,000 heritage designated properties in 24 communities. Moreover, Lazrak, F. Nijkamp, P. Rietveld, P. Rouwendal, J. (2011) have carried out research at Dutch city of Zaanstad using hedonic pricing method. According to the houses sold within a historic protected area, they appear to gain a premium of 26.4 per cent which confirms the existence of a historic ensemble effect. Further Chen, K. (2013) identified that the heritage designation had positive economic impact on the housing value at the Johnson City, Tennessee. Further Narwold, A. Sandy, J. Tu, C. (2008) investigated that $16 \%$ increase in housing value reason to heritage designation in the city of San Diego in California.

Moreover Winson-Geideman, K. Jourdan, D. (2010) research highlighted that there is no observable impact on the property value of heritage designated property. Further Zahirovic-Herbert, V. Chatterjee, S. (2011) mentioned that there is a positive impact on residential property value reason to designate as heritage property at Baton Rouge, Louisiana in USA.

\section{Method of Study}

\subsection{Heritage properties in Kandy, Sri Lanka}

Kandy is the last kingdom in Sri Lanka before British colonization. Today it is the administrative capital of the central province in Sri Lanka. Because of the Temple of tooth relic (Sri DaladaMaligawa) this city has high spiritual value. Moreover, today local and foreign tourist are attracted to the Kandy world heritage city.
In 1815 A.D., British were able to capture the Kingdom of Kandy. Therefore, Kings and British Administration had constructed administrative buildings, residential buildings and religious building within Kandy city for their administrative, commercial and religious purposes.

After gaining independence, the Kandy city developed as a major city in Sri Lanka. Further, it is popular as tourist destination and the city has rapidly developed because of the potentials of the city. Therefore, Kandy city has a high demand for land and new developments

With this situation, the built environment has also changed and it had negatively affected the historical image of the city. Considering historical and religious value in Kandy UNESCO has declared Kandy as a World Heritage City (KWHC) in 1987. They were declared 112 residential properties within KWHC.

\subsection{Sample selection}

Both qualitative and quantitative analysis methods were used for this research. The sample size in each analysis show in following diagram.

To analyze the use change of the (Heritage Designated Residential Property) HDRP, the total sample had been selected for this study. The properties, which are still used as residential properties, were selected for analysis of the physical condition of the property using regression analysis and sale price data analysis as the other 60 properties were converted to commercial and mixed uses and presently those properties cannot be considered as HDRP. 
Figure 5: Figure No 05 - Sample selection method

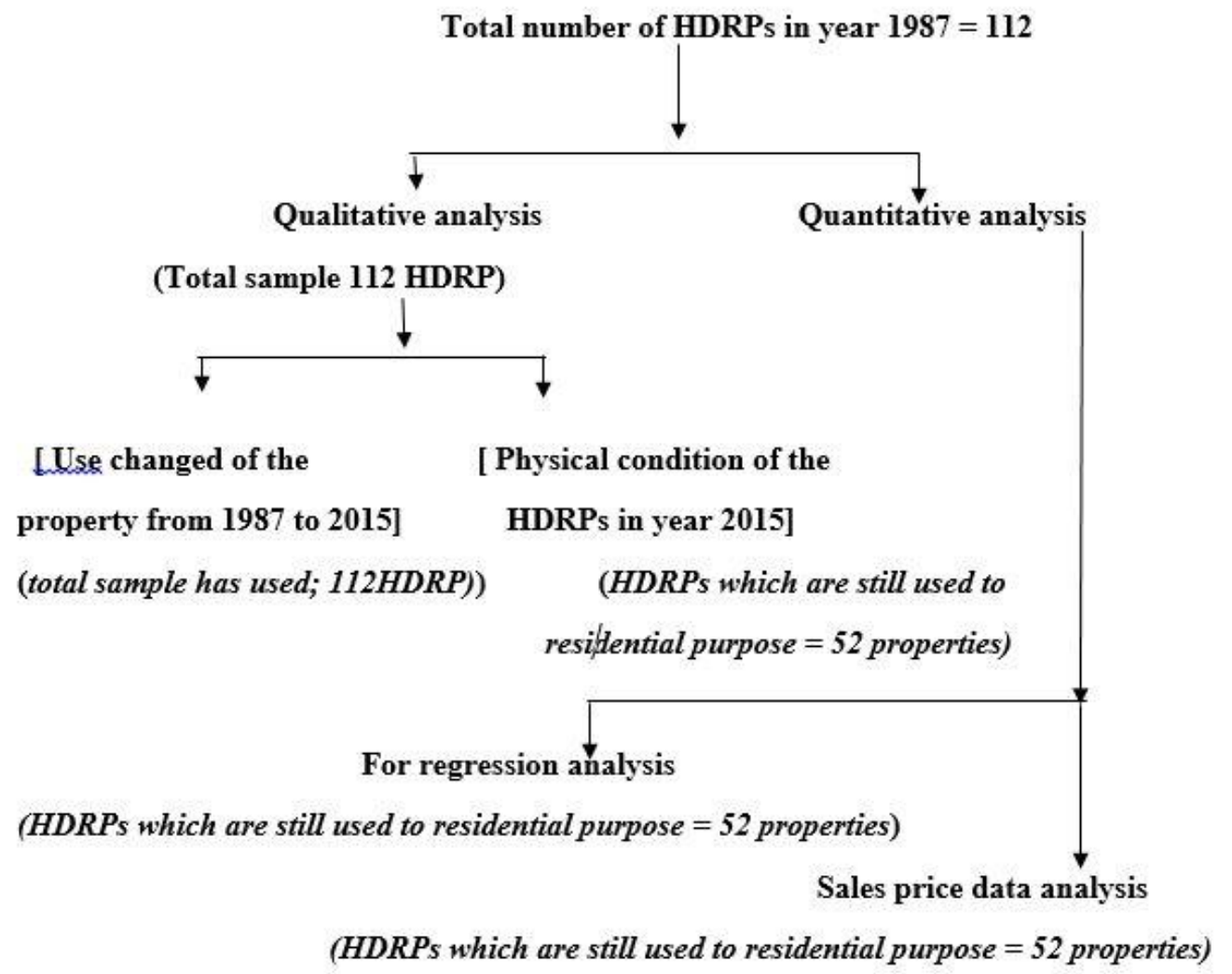

\subsection{Qualitative analysis}

This section focuses on the qualitative analysis of data, which was collected from the field observation. This qualitative analysis helps to understand the quantitative analysis results, which in turn explains the theoretical concepts in real at the ground situation.

a. Use change of the property

In year 2015, there were only 52 HDRP in the KWHC. According to the available data in the Regional Valuation Department at Kandy, in year 2000, a total number of 15 properties were converted for mixed use. Thus, parts of the residential property were converted as commercial space including 11 properties for commercial use. There were 86 properties used as residential property in the 2015, including11 properties used as mix use properties. Also, there were 49 properties used as commercial properties and 52 properties were kept as residential properties.

The method of preserving a historic building which was introduced by Jack Harvey in 2004, where he stated that that after period of time highest and best use as a house is getting reduce than the clear site value. That situation is common for every property. For the HDRP in that situation has fewer choices for redevelopment than the non-designated residential properties. According to Harvey when the highest and best use as a house reduces than the cleared site value, permission for office use will be the reason for the present capital value. When considering the KWHC situation, with the time change highest and best use of HDRP as 'house' is getting reduce. On one hand those properties are located in close proximity to the city center and with the time changes, those properties have a demand for commercial use than residential use. In that, 
situation people try to change the use of the property. In year 2000, 11 properties were converted to commercial use and 15 properties were converted to mixed use. Also, year 2015, 49 properties were converted to commercial use and 11 properties converted to mixed use. Through that people adapted to raise the present capital value of the property. However, the issue is when converting the use of HDRP, nearly $75 \%$ of property owners have not followed the special building regulation which those properties had to follow. Therefore, those properties have less historical and architectural value.

\section{b. Physical condition of the property}

There are three category of HDRP name as A, B, C in KWHC. HDRP has a legal resistance based on its category. According to that ' $A$ ' class properties has high legal resistance than the $\mathrm{B}$ and $\mathrm{C}$ category. Therefore HDRP have high maintenance cost than the other properties. Thus, when a heritage designated property goes to regenerate, the property owner can only use suitable material with it exist. There is no possibility to change the building façade, especially in 'A' class properties.

Meanwhile with the age of HDRP those properties are in poor physical condition (Physical condition evaluate based physical condition of super structure, color washing, level of maintained and physical outlook). According to the field observation from HDRP which are still used as residential properties (total 52 HDRP when year 2015), 27 properties are in poor condition, 09 properties are in fair condition and 16 properties are in good condition. As a percentage $52 \%$ HDRP are in a poor condition. According to the field observation the main reasons for that is high maintenance cost of the property.

c. Requirement of subsidy and quality of the building

When a period of time the highest and best use as a house is getting reduce than cleared site value of it. Reason to raise the cleared site value of the property than its highest and best use of the property, property owners adapt to change the use of it. The HDRP which does not change the use of it, has high maintenance cost. The HDRP haves special building regulations which the property owner has to follow. They have to conserve the historical features of it. According to Harvey from year 'D' (see figure no 03) subsidies required for the raise the present value of the property. In the KWHC situation, there is no government subsidy to maintain those HDRP properly.

Further Harvey said, in year ' $E$ ' (refer figure no 03) value as a 'historic house' of HDRP increases than the clear site value. This situation due to perfect inelastic supply of the HDRP. However to increase the value of HDRP, the property should be in a proper physical condition. When the properties physical condition is in poor, the property does not have a possibility to increase its value as a historic building.

\subsection{Quantitative analysis}

This analytical process consists of quantitative part which used two kinds of property value data.

Annual property value data from Regional Valuation Department in Kandy.

Sales price data of the property

First part of quantitative analysis was based on annual property value data from regional valuation department in Kandy. This data was used for regression analysis. 


\subsection{Attributes of housing value}

There are many attributes, which affect residential property value. According to the Kain and Quigley (1975) housing attributes of a single family house were dwelling quality, Size of the property, Neighborhood characteristics, Structure type.

This attributes are significantly diversified and they change from country to country and society to society. Except to this attributes there are some external attributes, which also affect the value of residential property. Inflation rate, government policies are examples of these.

\subsection{Selected attributes for regression analysis}

For regression analysis in this research, three attributes were selected. They were;

Total square foot of the property

Distance to city center

Except these two attributes, there is a dummy variable selected for measuring the historical impact on the property. When using a dummy variable it has only two categories. It may be 01 (one) or 0 (zero). In this regression analysis 01 was added for heritage designated properties and 0 add for non-designated residential properties.

Total square foot of the property selected as one attribute that was the size of the property. Square foot of each storey were included in to this.

Distance to city center was considered as the second attribute. According to the valuation standards in Sri Lanka the clock tower in a city was considered as the city center. In general, when a property is located near the city center, it has high property value and when the property goes beyond the city center there was less market value.

In this research except these two attributes and one dummy variable, other attributes were considered as constant. For example, accessibility for the property has same width roads and same condition. When considering the neighborhood characteristics, all the heritage designated residential properties are located at city core area and it has highly commercialized environment and nondesignated residential properties which were also located in close proximity to the city center (within $02 \mathrm{Km}$ radiance from the city center).

\section{Findings Results from the regression analysis}

This section discusses the result of the analysis, which was done by using annual property value data using the Minitab software. As mentioned above three attributes were selected for the analysis. Size of the property measure based on square foot, distance to city center as on 'meter' and there is a dummy variable for measure the heritage effect (Reason to normalize distribution of the data set there was no need for add the log value for the model and in a regression analysis R-squared shows how close the data to the fitted regression line. In this regression analysis R-Squared value is 69\%). According to the analysis following regression equation got as output.

$\mathrm{C} 1=47042+27.3 \mathrm{C} 2-10994 \mathrm{C} 3-27.2 \mathrm{C} 4$

$\mathrm{C} 1=$ Annual value of the property

$\mathrm{C} 2=$ Total square foot of the property

C3 = Dummy variable

C4 = Distance to city center

$47042=$ constant value

Here is analytical result from the Minitab software. 
Table 1 - Regression analysis results

\begin{tabular}{|c|c|c|c|c|}
\hline Predictor & Coefficient & $\begin{array}{c}\text { Standard } \\
\text { Error } \\
\text { Coefficient }\end{array}$ & $\begin{array}{c}\text { 'T' } \\
\text { Value }\end{array}$ & $\begin{array}{c}\text { 'P' } \\
\text { Value }\end{array}$ \\
\hline Constant & 47042 & 11800 & 3.99 & 0.000 \\
\hline C2 & 27.284 & 1.922 & 14.20 & 0.000 \\
\hline C3 & -10994 & 6215 & -1.77 & 0.080 \\
\hline C4 & -27.243 & 9.797 & -2.78 & 0.006 \\
\hline
\end{tabular}

$\mathrm{S}=30718.2$

$\mathrm{R}-\mathrm{Sq}=69.9 \%$

$\mathrm{R}-\mathrm{Sq}(\operatorname{adj})=$ $69.0 \%$

Above-mentioned result can be conclude as follow;

$\mathrm{C} 1=47042+27.3 \mathrm{C} 2-10994 \mathrm{C} 3-27.2 \mathrm{C} 4$

C2 indicate the variable of the Total Square foot of the property. For that variable, it has a pulse $(+)$ value (+27.3C2). Hence, there is a positive impact on the annual value of the property. When considering the ' $\mathrm{P}$ ' value it is 0.00 . It indicate that the variable has a meaningful addition for the model. Meanwhile ' $\mathrm{T}$ ' value has significant deferent form the zero (' $T$ ' value is 14.20). It indicate that variable is significant for the model.

C3 indicate the dummy variable of designated and non-designated properties. For that variable, it has a negative (-) value. Thus, heritage designation has a negative impact on the annual value of the property. When considering the ' $\mathrm{P}$ ' value is 0.080 . It indicates that the variable does not have a meaningful addition for the model. Because ' $\mathrm{P}$ ' value is higher than the 0.05. Moreover ' $\mathrm{T}$ ' value has not a significant deferent from the zero (' $\mathrm{T}$ ' value is 1.77). It indicate that variable is not significant for the model.

C4 indicates the variable of distance to city center. For that variable, it has a negative (-) value. Therefore, there is a negative impact on the annual value of the property. When considering the ' $\mathrm{P}$ ' value is 0.006 . It indicates that the variable has a meaningful addition for the model.

According to the above analytical results, total square foot of the property has a significant positive relationship to the annual value of the property. When determining an annual value of a property, square foot of the property is important factor for it. After that the distance to city center (C4) can be considered as the second most important factor for determining an annual value of a property. Distance to city center has a negative relationship between the annual values of the property. Heritage designation of a property (C3) also has a negative relationship with the annual value of the property. However, according to the ' $\mathrm{P}$ ' and ' $\mathrm{T}$ ' value are not a meaningful addition for the annual value of the property. Therefore, a heritage designation does not significantly affect the annual value of the property.

When considering the above regression analysis, the most significant variable is total square foot size of the property. To measure how total square foot of the property significant for determination of annual property value only on HDRP following regression analysis is followed;

$\mathrm{C} 1=49405+29.1 \mathrm{C} 2-111 \mathrm{C} 3-33.9 \mathrm{C} 4$

$\mathrm{C} 1$ = Annual value of the HDRP

$\mathrm{C} 2=$ Total square foot of the property

C3 = Age of the property

C4 = Distance to city center

Table 2: Regression analysis results

\begin{tabular}{|l|l|l|l|l|}
\hline Predictor & \multicolumn{1}{|c|}{ Coef } & $\begin{array}{c}\text { Standard } \\
\text { Error } \\
\text { Coefficient }\end{array}$ & $\begin{array}{c}\text { 'T' } \\
\text { Value }\end{array}$ & $\begin{array}{c}\text { 'P' } \\
\text { Value }\end{array}$ \\
\hline Constant & 49405 & 22363 & 2.21 & 0.032 \\
\hline C2 & 29.072 & 2.018 & 14.41 & 0.000 \\
\hline C3 & -111.3 & 139.3 & -0.80 & 0.428 \\
\hline C4 & -33.90 & 13.88 & -2.44 & 0.018 \\
\hline \multicolumn{4}{|r}{ S = 28517.0 R-Sq $=81.6 \%$} \\
r R-Sq
\end{tabular}

(adj) $=80.5 \%$ 
According to this regression analysis, when determining the HDRP annual value, the total square foot size is the most significant variable.

\subsection{Sale price data analysis}

According the regression analytical result, heritage designation of residential property value does not significantly affect it property value. To investigate that situation with the real market value, this research compared the sales price value of HDRP and the average per perch value in the same area. Five HDRP sold within year of 2015. In this context, per perch value of the sold HDRP compare with the average per perch value in the same area. The following table provides the per perch value of HDRP value and average per perch value in the same area.

The data gathered from survey illustrates that there is no significant difference between per perch value of HDRP and the average per perch value in the same area. It has only a small value difference between the HDRP and average per perch value in the same area. Referring to the table, assessment no. 45 house in Deva Veediya was sold at 18 million per perch and it is only less than Rs.200, 000 from the average per perch value. In D.S. Senanayake road assessment no. 220 house were sold for less than the Rs. 200,000 from per perch value and assessment no. 308 sold less than 100,000 from the average per perch value. In the Peradeniya Road assessment no. 355 house was sold for less than the Rs. 200,000 from per perch value and assessment no. 445 house was sold for less than the Rs.300, 000 from per perch value. This results justify the analytical result which the analysis based on according to annual property value data in Department of Valuation.
Referring to the regression analysis which was done using annual property value data, the heritage designation does not significantly impact on the annual property value. It indicates through ' $\mathrm{P}$ ' and ' $\mathrm{T}$ ' value in regression analysis. The most significant variable is the square foot of the property and the variable of distance to city center is significant after that.

This analysis justify the sales price data of HDRP value in Kandy, which was discussed in above. The HDRP was able to sale in the property market more close to the average per perch value in the same area.

In conclusion this analysis shows the heritage designation of residential property value does not significantly affect the real market value of the properties. When determining the annual value of the HDRP, total square foot of the property significantly affects its property value. Further Harvey \& Jowsey (2004) said heritage designated residential properties will be able to raise its capital value as historic house than the clear site value after a period. In that situation low scale properties have less possibility in raising its capital value compared to large scale properties reason to significant of size of the property variable. Moreover, low scale properties have less historical architectural features compare to the large-scale properties.

In Kandy situation those heritage designated residential properties demand for some adaptive use like put up hotels and tourist attract shops. In that situation large scale properties with having high architectural features got more demand than the low scale properties. 


\section{Conclusion}

This research show that there is no significant impact on residential property value on the based on designated as heritage property. However, according to the research based on KWHC, the every HDRP does not have the same possibility to increase its property value than the clear site value. The regression analysis shows the variable which is most affected by annual property value which is the size of the property (total square foot of the property). While the large scale properties has high architectural features than the low scale properties. This is due to large-scale properties which have a high possibility to increase its capital value than the clear site value of it compare to small scale properties.

The condition of the properties also directly affect in the increase in capital value of the HDRP value, than it clear site value. When the physical condition of the property reduces the historic value is also reduced also because of the poor physical condition. The Field observation said that the main reason for poor physical condition of the property is high maintenance cost of it. In KWHC, there is no subsidies for HDRP to cover it maintenance cost. According to Harvey (2004) when the clear site value increases than the capital value government has to provide some subsidies for HDRP to cover it maintenance cost.

Further Professionals who engage in urban conservation should have pay attention to the scale of the properties before conserve it. In the Sri Lankan context, properties are designated as heritage property mainly based on age of the property. However when a declared a property as heritage property, conservationist should pay attention to the scale of the property and what is the level of it contribution to image of the city as heritage property. (This conclusion is only for those heritage properties, which are, belong to real property market and there may be some exceptional situation like the property may be unique for the history of particular society).

\subsection{For future researchers}

This research is done based on Kandy city. It has an urban environment and those HDRP mixed with newly construct properties. Except to this in some cities declared as heritage district and all the properties, conserve as heritage properties. In that situation, the result may be change reason to positive externalities of each properties. Other than that, this research can be done for commercial properties also.

For the regression analysis, only two variable and one dummy variable were considered here. If the number of variable increase the result would slightly change. 


\section{Reference}

Ahlfeldt, G.M., Holman, N.,Wendland, N., (2012). An assessment of the effects of conservation areas on value. Final report May 2012. The London school of economics and political science.

Ahmad, Y. (2006). The Scope and Definitions of Heritage: From Tangible to Intangible International.Journal of Heritage Studies. Vol. 12, No. 3, May 2006, pp. 292-300

Antiquity (Amendment), Act No 24 of 1998. Published as a supplement to part ii of the gazette of the Democratic Socialist Republic of Sri Lanka of May 22, 1998. Printed at the Department of Government Printing.

Central Cultural Fund, Act no 57 of 1980. Available from: URL: https://www.archaeology.lk/wp-content/uploads/2015/04

Chen, K. (2013). The Making of a Historic District and the Economic Impact upon Housing Value: An Empirical Analysis of the Tree Streets Neighborhood in Johnson City, Tennessee. Available from: URL: http://dx.doi.org/10.4236/me.2013.412090

Dubben, N., Williams, B., (2009). Partnership in Urban Property Development; England: A John Wiley \& Sons, Ltd., Publication

Edirisinghe, J. Chandratilaka, W.N. (2014) Impacts of Historical Buildings on Real Estate Development in Colombo, Sri Lanka. International Journal of Physical and Social Sciences. Volume 4, Issue 10 (2014)

Edirisinghe, J. Ranasinghe, M. (2003) Conservation of historic buildings in urban settings.Paper presented at the 9th International Conference on Sri Lankan Studies University of Ruhuna, 28th - 30th November 2003

Finch,J. Howard. (1996). Highest and Best Use and the Special-Purpose Property'. The Appraisal Journal (April).

Harvey,J., Jowsey,E., (2004). Urban Land Economics. (6th Ed.). New York: Palgrave Macmillan.

John F. Kain, 1975. Housing Markets \& Racial Discrimination: A Microeconomic Analysis (Urban \& Regional Studies; No. 3). Edition. Univ Microfilms Intl

Lazrak, F. Nijkamp, P. Rietveld, P. Rouwendal, J. (2011). The market value of listed heritage: An urban economic application of spatial hedonic pricing. Research Memorandum 201127,VU University Amsterdam.

MacLennan, D., (1982). Housing Economics: An Applied Approach. Edition. Longman Group United Kingdom.

Narwold, A. Sandy, J. Tu, C. (2008) Historic Designation and Residential Property Values. International.Real Estate Review 2008 Vol. 11 No. 1: pp. 83 - 95. Available from: 
Rypkema, D. (2012) Heritage Conservation and Property Values. The economics of uniqueness. Editors, Guido Licciardi, RanaAmirtahmasebi. Published by The World Bank, Washington DC (2012).

Shipley, R. (2000) Heritage Designation and Property Values: Is there an Effect? The International Journal of Heritage Studies Volume 6.

Valuing Cultural Heritage: Applying Environmental Valuation Techniques to Historic Buildings, Monuments and Artifacts (2002). 0 Edition. Edward Elgar Pub.

Winson-Geideman, K. Jourdan, D. (2010) Historic facade easements and single-family home value: a case study of Savannah, Georgia (USA). International Journal of Housing Markets and Analysis Vol. 4 No. 1, 2011 pp. 6-17

Zahirovic-Herbert, V. Chatterjee, S. (2011) Historic Preservation and Residential Property Values: Evidence from Quantile Regression. Urban Studies. 49(2) 369-38 